\title{
REVISION OF THE CHILEAN SPECIES OF EMPIDIDAE (DIPTERA) DESCRIBED BY J. MACQUART
}

\author{
José A. Rafael ${ }^{1}$
}

\begin{abstract}
Four Chilean species of Empididae (Diptera) are revised: Aplomera pachymera (Macquart, 1838), A. gayi Macquart, 1838, Empis nudipes Macquart, 1838 and E. polita Macquart, 1838. Aplomera chilensis (Bezzi, 1909) was also studied and it is being considered junior synonym of A. pachymera. Empis nudipes Macquart, 1838 is confirmed to be a junior synonym of $A$. gayi Macquart, 1838. Lectotype is being designated for $A$. pachymera, A. chilensis and $E$. polita. Illustration of terminalia and photomicrographs of wings are also included.
\end{abstract}

KEYWORDS. Chile, Macquart's types, new synonym, taxonomy.

\section{INTRODUCTION}

MACQUART (1838) described five neotropical species of Empididae, of which four being from Chile. The fifth species was described later from Brazil (MACQUART, 1846). He described three Chilean species originally in the genus Empis Linnaeus: E. pachymera, E. nudipes. The latter species remains in its original combination and the first two species are presently in the genus Aplomera Macquart. The fourth Chilean species Aplomera gayi (senior synonym of Empis nudipes) remains in the genus Aplomera.

All Chilean types, deposited in the Museum National d'Histoire Naturelle, Paris, were studied. The type of the fifth species (Rhamphomyia nigriventris Macquart, 1846), described from Minas Gerais, was not located.

\footnotetext{
1. Instituto Nacional de Pesquisas da Amazônia (INPA); Caixa Postal 478; 69011-970, Manaus, AM, Brasil. Fellow of the CNPq (jarafael@inpa.gov.br).
} 


\title{
MATERIAL AND METHODS
}

The studied types belong to the Museum National d'Histoire Naturelle (MNHN), Paris, France and Staatliches Museum für Tierkunde (SMT), Dresden, Germany. Other examined specimens belong to the Canadian National Collection of Insects (CNC), Ottawa, Canada and Instituto Nacional de Pesquisas da Amazônia (INPA), Manaus, Brazil.

Wing detached from each specimen was mounted on a microslide with balsam and the terminalia was placed in a microvial with glycerin. The microslide and/or microvial were pinned along with the specimen. Terminology and abbreviations are based on MCALPINE (1981), except for male terminalia that follows CuMMING et al. (1995). The square brackets in the "Material examined" are used to indicate information not included on the original label. Labels are cited in full from the top down with data from each label enclosed in quotation marks. Each label is delimited by a slash mark.

\section{Aplomera pachymera (Macquart, 1838)}

\author{
(Figs. 1-6, 17)
}

Empis pachymera MACQUART, 1838:279; PhILIPPI, 1865:753; BeZZI, 1905:457; 1909:346; MELANDER, 1928:167. Aplomera pachymera; ColuIN, 1933:164, FIGS. 34A-C; SMITH, 1967:27.

Haplomera chilensis BezzI, 1909:374; Melander, 1928:131; Collin, 1933:161; Sмith, 1967:27. NEW SYNONYMY.

Diagnosis. Dark brown to black with gray pruinescence; front and face bristled; male face half as wide as frons; palpus light yellow; thorax with four dark longitudinal stripes; anterior acrostichal bristles uniserial becoming biserial posteriorly; legs, halter and basal sternites yellow; female mid femur with longer posterior and posteroventral chestnut bristles; all tibiae with small downward sloping spines ventrally; all tarsi with tarsomeres rather bicolored, predominantly brown, yellow at extreme base, more conspicuous on fore tarsus; female tergites 3-5 and male tergites 3-6 with gray pruinescence across posterior margin, more conspicuous in female; costal vein becoming evanescent at level of vein $\mathrm{CuA}_{1}$.

Redescription (based on male lectotype of Aplomera chilensis Bezzi that is in better condition). Body length $4.4 \mathrm{~mm}$; wing $4.5 \mathrm{~mm}$. Head (fig. 1). Eyes dichoptic; bigger facets placed between antenna and proboscis. Frons gray pruinose, slightly narrower than ocellar triangle, slightly higher than upper width, slightly convergent near antenna, with 5 pairs of bristles, the lower pair bigger than upper ones. Face gray pruinose, with small slender lateral bristles, almost twice as high as frons, about half of the frons width, slightly divergent near proboscis, with apex slightly protuberant. Palpus light yellow, slender, upcurved with distinct light bristles and apex clavate. Proboscis dark yellow, one third longer than the height of the head. Ocellar triangle slightly protuberant with yellow ocelli; anterior ocellar bristle small and divergent, slightly stronger than the 3-4 posterior ones. Antenna with scape, pedicel and extreme base of the flagellum dark yellow, the remaining tip velvety black; scape two times longer than pedicel, flagellum almost three times longer than scape and pedicel together and five times longer than stylus. Postcranium chestnut, densely gray pruinose with small bristles, being the upper bristles apparently biserial, darker and stronger than lower multiserial bristles; upper postocular bristles slightly stronger and darker than lower ones; vertical bristles subequal in size to the adjacent postocular bristles. Genae and postgenae with white slender bristles. Thorax (fig. 2) dark brown to black, gray pruinose; postalar callus slightly yellow; scutum with four dark longitudinal stripes between acr and dc and between dc and spal row of bristles, the latter conspicuous and at certain lights 


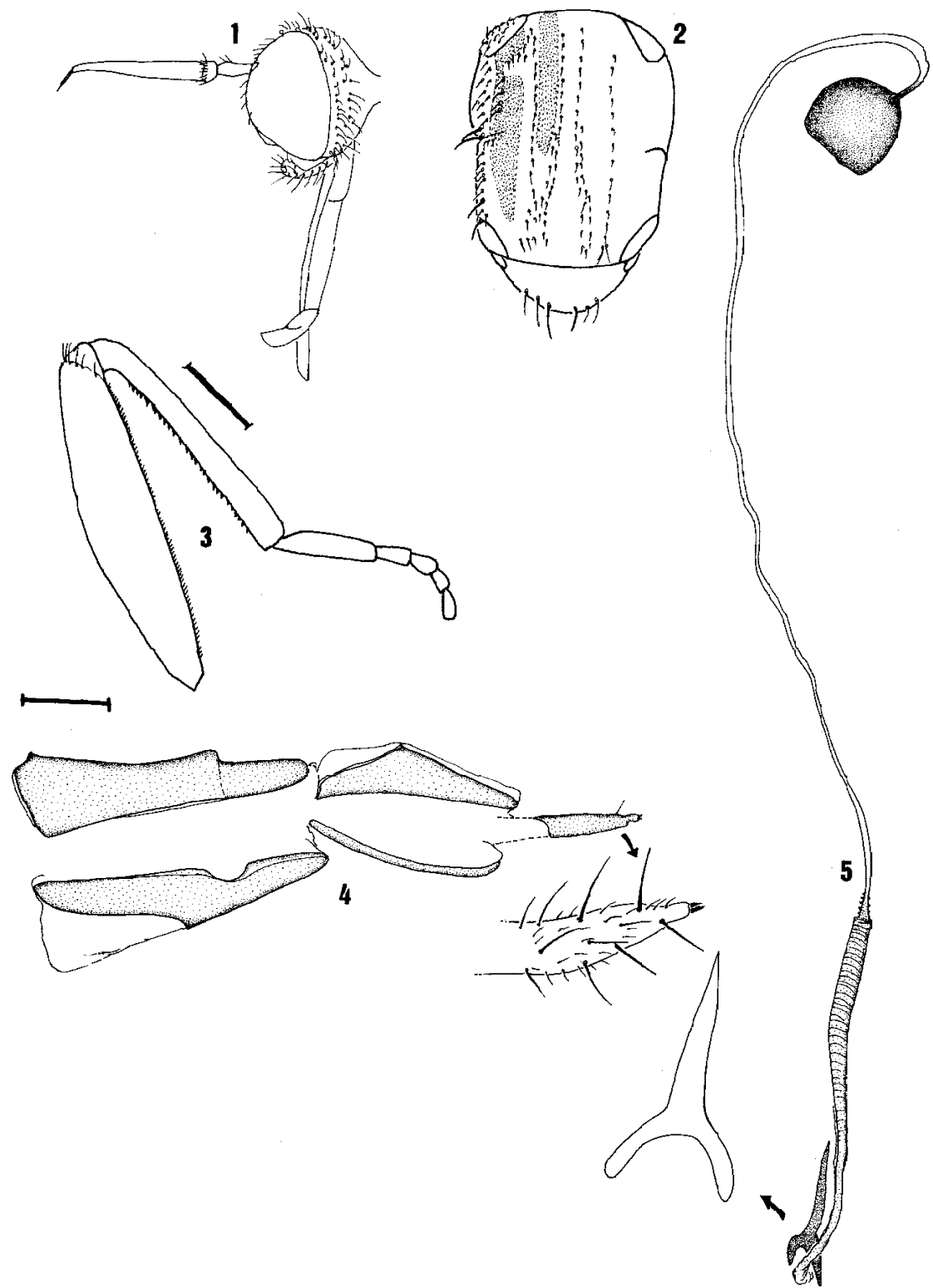

Figs. 1-5. Aplomera pachymera: 1, head, left lateral view (lectotype on of Aplomera chilensis); 2, thorax, dorsal view (paralectotype ${ }^{n}$ of $A$. chilensis); 3, right hind leg, anterior view (idem); 4, female terminalia, left lateral view, bristles not represented, except in the detailed cercus (specimen from Santiago, Apoquimbo, CNC); 5, spermatheca with detailed genital fork (idem, CNC). Bars: 0,5 mm, figs. 1-3; 0,1 mm, figs. 4, 5 . 

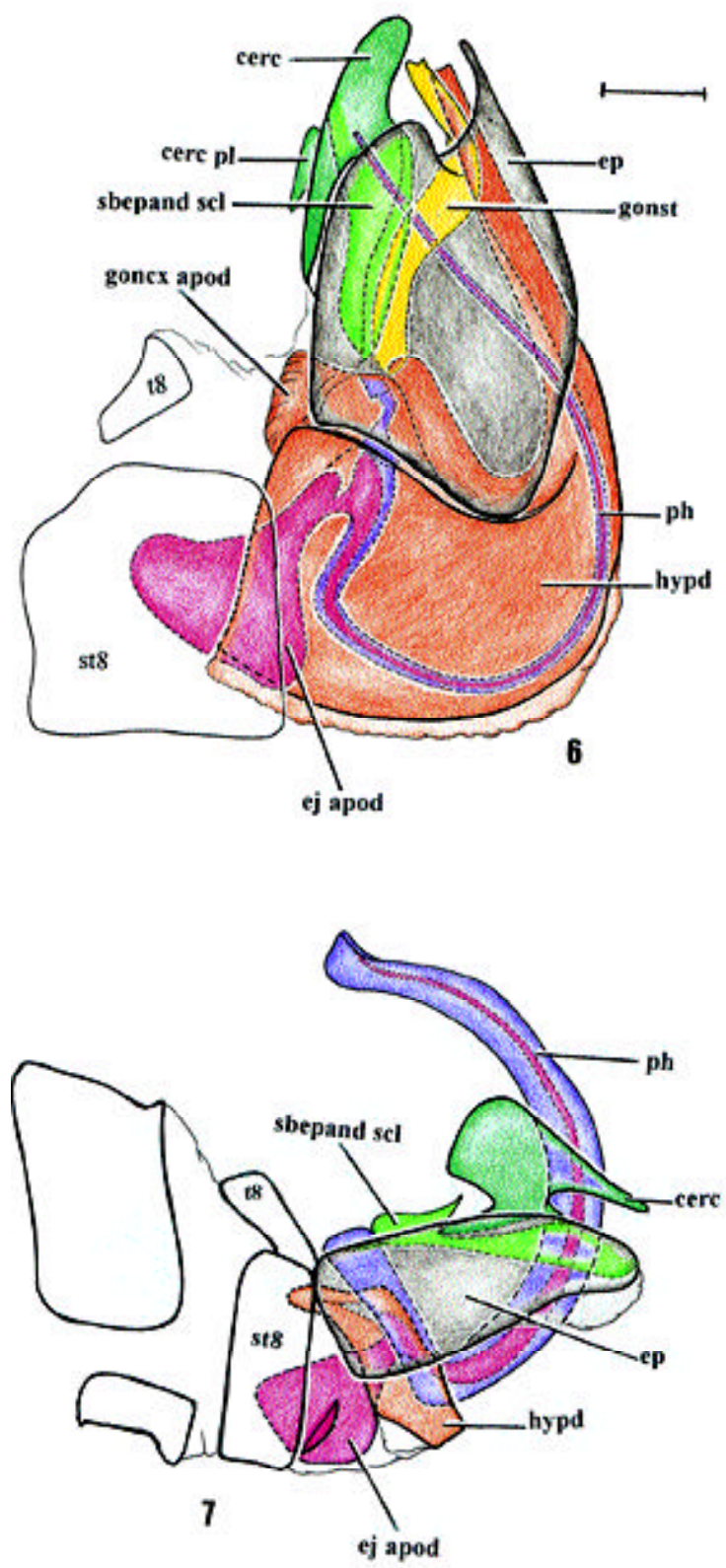

Figs. 6-7. Male terminalia (bristles not represented). 6, Aplomera pachymera, left lateral view (paralectotype of Aplomera chilensis); 7, Empis polita, left lateral view (specimen from Santiago, Penalolén, CNC). Abbreviations: cerc, cercus; cerc pl, cercal plate; ej apod, ejaculatory apodeme; ep, epandrium; goncx apod, gonocoxal apodeme; gonst, gonostyle; hypd, hypandrium; ph, phallus; sbepand scl, subepandrial sclerite; st, sternite; t, tergite. Bar: $0,1 \mathrm{~mm}$. 
incidence divided into two spots, one small spot behind postpronotal lobe and one bigger behind small spot. Bristles (fig. 2) predominantly small, light and slender: 5-6 aprn, the lateral stronger; about 10 subequal pprn; 6-7 slender prepst; many slender prepm; acr small, distinct, uniserial until transverse suture level becoming biserial, farther more apart posteriorly; dc uniserial subequal to acr in size, the latter bristle of each row slightly stronger and black; 4-5 ial presut; 2-3 ial psut arranged transversally; 4-5 spal presut; 5-6 spal psut, the penultimate bristle stronger; 2 posterior npl strong and many anterior weak; 1 pal strong; 3 sctl, the apical stronger and convergent. Legs yellow except dorsal face of femora and dorsal face of tarsi brown, the latter yellow at base of the tarsomeres. Trochanters with small shining black spot at apex of the ventral face. Femora enlarged, especially hind femur (fig. 3). First fore tarsomeres enlarged. All femora with fine white pubescence ventrally among which there are small spiniform denticles, distinct in lateral view. Mid femur with chestnut posterior and posteroventral bigger bristles. All tibiae with small downward slope spines ventrally. Wing (fig. 17) hyaline with brown veins; base of the costa without any strong bristle; pterostigma tenue, light brown at apex of the costal cell and part of the $r_{1}$ cell; vein $R_{5}$ ending below the wing apex. Halter light yellow. Abdomen dark brown with gray pruinescence in anterior view; light brown, subshinning in dorsal and posterior view with gray pruinescence laterally; bristles light, distinct, longer laterally. Tergites with uniserial bristles slightly stronger on posterior margin. Sternites lighter than tergites, the basal ones yellow. Terminalia (fig. 6): hypandrium with acute posterodorsal projection; gonostyle curved.

Female (redescription based on female paralectotype of Empis pachymera). Body length $4.9 \mathrm{~mm}$; wing $4.5 \mathrm{~mm}$. Agree in all respects with male redescription, except by 1 posterior npl bristle; mid femur with longer posterior and posteroventral chestnut bristles; tergites 6-8 with narrow yellowish bands across posterior margin, more conspicuous in posterior view. Terminalia (fig. 4): tergite 8 bifid at apex; tergite 10 membranous medially at basal two thirds; cerci short with pointed apex slightly outcurved. Spermatheca and genital fork as in fig. 5 .

Material examined. Type of A. pachymera: lectotype $\sigma^{-1}$ (pres. desig.) (MNHN) [green rounded label with under face manuscript number] "670 97" / [white label with manuscript name] "Empis pachymera male" / [white label manuscript] " $n^{\circ}$ 1577, E. pachymera Macquart, 2 spéc." / [blue label added by this author] "Lectotype o", Aplomera pachymera (Macquart)"; Paralectotype Y, MNHN/ [green rounded label with under face manuscript number] "670 97" / [white label manuscript] "no 794, Empis pachymera" / [blue label added by this author] “paralectotype Y, Aplomera pachymera (Macq.)". Type Material of A. chilensis: CHILE, Concepción, 10.IX.1902 [150 m] (lectotype o', SMT); [Valparaiso], Quillota, 22.IX.1902, [1000 m] (paralectotype o', SMT). More than 300 specimens from Chile, most of them from Santiago, Apoquimbo, IX.1954, L.E. Peña (CNC); 10 specimens from CNC series deposited at INPA.

Lectotype conditions. Lectotype of A. pachymera: body covered with dry fungi; left antenna and right wing absent. Left wing mounted on a microslide and terminalia placed in a microvial. Lectotype of A. chilensis: forelegs and left midleg lost; terminalia, strongly clarified by potassium hydroxide solution, placed in a microvial with glycerin.

Observation. One specimen of $A$. chilensis did not have type label; it only had a label with the following identification "Hilarempis argentifera Bezzi". However, there is no doubt that the specimen belongs to the typical series of $A$. chilensis and it is being labeled as $A$. chilensis as well.

Variation. The lectotype of $A$. pachymera presents brown scape and pedicel. The paralectotype of $A$. chilensis presents only a pair of frontal bristles and is bigger $(5.5 \mathrm{~mm})$. 


\section{Aplomera gayi Macquart, 1838}

(Figs. 8-10, 18, 20)

Empis nudipes Macquart, 1838:277, pl. 13, fig. 2; PhilipPI, 1865: 753; BezZI, 1905:457 (treated as junior synonym of A. gayi by CoLLIN (1933), whereby it is not available according the IcZN (1985), art. 24, principle of the first reviser).

Aplomera gayi MACQUART, 1838:279, pl. 13, fig. 4 (in the plate it was used the generic name Anodontina, a mistake); PhilipPI, 1865:758; BezzI, 1905:458; 1909:373; Melander, 1928:131; Collin, 1933:162, figs. 32b, 33a-g; SмIтн, 1967:27.

Aplomera nudipes; BeZZI, 1909: 373; Melander, 1928:131; Sмith, 1967:27.

Diagnosis. Dark brown to black with gray pruinescence; frons and face bristled; face about two thirds as wide as frons; palpus light brown; thorax with four dark longitudinal stripes; acrostichal bristles uniserial anteriorly, becoming biserial posteriorly; legs dark brown to black; female mid femur with longer posterior and posteroventral black bristles; all tibiae with small downward sloping spines ventrally; male fore tarsus bicolored, mainly brown except at extreme base of tarsomeres 2-5 yellow; female tergites 3-5 and male tergites 3-7 with gray pruinescence across posterior margin, more conspicuous in posterior view, especially in female; costal vein becoming evanescent at level of vein $\mathrm{CuA}_{1}$.

Redescription. ColLin (1933) adequately redescribed this species from the female holotype of A. gayi. I add figures 8-10, 18, 20 and some characters for better recognizing the species. Body length $6.5 \mathrm{~mm}$; (from Coluin, 1933); wing $5.9 \mathrm{~mm}$. Palpus brown to black. Thoracic bristles damaged (probably identical to figure 2 of A. pachymera). Legs brown to black, all femora with soft whitish pile ventrally among which there are small spiniform denticles, more conspicuous on hind femur. Scutellum with four pairs of small bristles, being two pairs slightly longer. Wing (fig. 18) wider than in male. Halter brown to black. Terminalia with T8, T10 and cercus as in figs. 8, 9 .

The male was redescribed in the same paper based only on differential characters. Holotype male of $A$. nudipes: body length $6.5 \mathrm{~mm}$; wing $5.7 \mathrm{~mm}$; larger facets presents between the base of antenna and the proboscis; ocellar bristles small. Wing as in fig. 20. Terminalia as in fig. 10.

Material examined. Holotype of $A$. nudipes (MNHN). [green rounded label with under face manuscript number] "670 97" / [White label with manuscript name] "nudipes" / [White label manuscript] " $\mathrm{n}$ " 1576, E. nudipes Macquart 1 spéc." / [A red label added by this author] "Holotype ${ }^{-1}$, Aplomera nudipes (Macq.)". The type of A. nudipes is a male and not a female as described by Macquart and as previously noted before by CoLLIN (1933). Holotype 9 of A. gayi (MNHN) [green rounded label with under face manuscript number] "670 97 / [White label manuscript] " $\mathrm{n}^{\circ}$ 766, Aplomera gayi" / [White label manuscript] " $\mathrm{n}^{\circ}$ 1579, A. gayi Macquart, 1 spéc. / [A red label added by this author] "Holotype 9 , Aplomera gayi Macq.". CHILE, Santiago, Apoquimbo, IX.1954, L.E.Pena ( $\sigma$, CNC); Coquimbo, Illapel, 1500-1800 m, 1-6.XI.1954, L.E. Pena ( INPA); Hda (sic) Illapel, 28.V.1954 ( CNC); Santiago, Pudahuel, II.1954 (2 CNC); Santiago, IX.1953, L.E. Pena ( $\sigma^{\prime}, C_{C N C}$ ).

Holotype conditions. A. nudipes: body covered with dry fungi; both flagellum absent; thorax with exude; left wing partially broken at pterostigma level; abdomen glued to the pin; right wing mounted on a microslide and the terminalia placed in a microvial, both pinned along with the specimen. A. gayi: body covered with dry fungi; both flagellum, left wing and right midleg absent; right wing mounted on a microslide and the terminalia placed in a microvial. 
Discussion. A. gayi is closely related to $A$. pachymera and they are only securely identified based on their size. The body length of $A$. gayi varied from 6.5 to $7.5 \mathrm{~mm} ; A$. pachymera varied from 4.5 to $6.0 \mathrm{~mm}$.

\section{Empis polita Macquart, 1838}

(Figs. 7, 11-16, 19)

Empis polita Macquart, 1838:278; PhilipPI, 1865:753; BezZI, 1905:458; 1909:355; Melander, 1928:169; Collin, 1933:238, fig. 52a; SмIтH, 1967:24.

Empis collina PHILIPPI, 1865:736; BeZZI, 1905:457; 1909:347; Melander, 1928:169 (as doubtful synonym of polita); Collin, 1933:238.

Diagnosis. Black, with mid tibia dark chestnut; apex of the hind femur and hind tibia and first tarsomere yellow; halter light yellow; face bare; supracervical bristles present.

Redescription. Lectotype female (pres. desig.). Body length $5.5 \mathrm{~mm}$; wing 5.7 $\mathrm{mm}$. Eyes with small incision at level of antenna. Frons and face wider than ocellar triangle, both about as wide as high, gray-brown pruinose, with 4-5 bristles laterally, lower one the longest. Face bare. Ocellar triangle slightly protuberant, sparsely pruinose. Frons with 3-4 pairs of bristles, one being the longest. Postcranium gray pruinose with black bristles; upper post-ocular bristles longer than lower ones, curved upon the eyes; occipital apparently biserial; gena and post-gena with soft bristles. Antenna black, flagellum velvety black; scape almost twice as long as pedicel, both with dark bristles; flagellum about 1.5 times as long as stylus and almost 2.0 times longer than scape and pedicel together. Proboscis almost twice as long as height of the head. Palpus brown, upcurved, with long black bristles.

Thorax black, gray pruinose dorsally with longitudinal stripes. Mesopleura color variable according to the light incidence. Scutum (fig. 11) with 5 longitudinal dark stripes all intercalated with gray pruinescence that change color according to light incidence; the median dark longitudinal stripe is located under acr bristles, paramedian stripe under dc bristles and the lateral stripe under lateral bristles; gray stripes are between acr and dc and between dc and lateral bristles. Bristles (most damaged and observed from the alveoli): 5-7 uniserial aprn; 8-10 pprn being 1 longer; 2-3 prepst; 810 prepm, the lower longer; acr uniserial ending before dc row; dc apparently biserial anteriorly, becoming uniserial medially and turning biserial again posteriorly, the posterior bristles longer; 4-6 ial presut; 2-3 ial psut near transverse suture; 2-3 spal presut, the median longer; spal psut not observed; about $6 \mathrm{npl}, 2$ posterior longer; 2 pal, the posterior longest; 3 sctl and 15-20 ktg of different size.

Legs black with a tendency to be dark tawny on mid tibia and first tarsomere and yellow on mid knee, apex of hind femur ventrally, all hind tibia except apex brown, and large base of hind first tarsomere brown. Legs slightly gray pruinose according to light incidence. All femora with anteroventral and posteroventral rows of bristles slightly longer, hind femur with 4 anteroventral bristles on distal fourth and 1 posterior and 1 posteroventral bristle both at apex, ventrally white pubescent. Fore tibia (fig. 12) with 4-5 anteroventral and posteroventral bristles equally spaced, besides 1 posterior and 1 posteroventral bristle at apex; first tarsomere with 1 ventral bristle at base and 4 anteroventral and posteroventral short bristles. Mid tibia (fig. 13) with 4-5 equally 

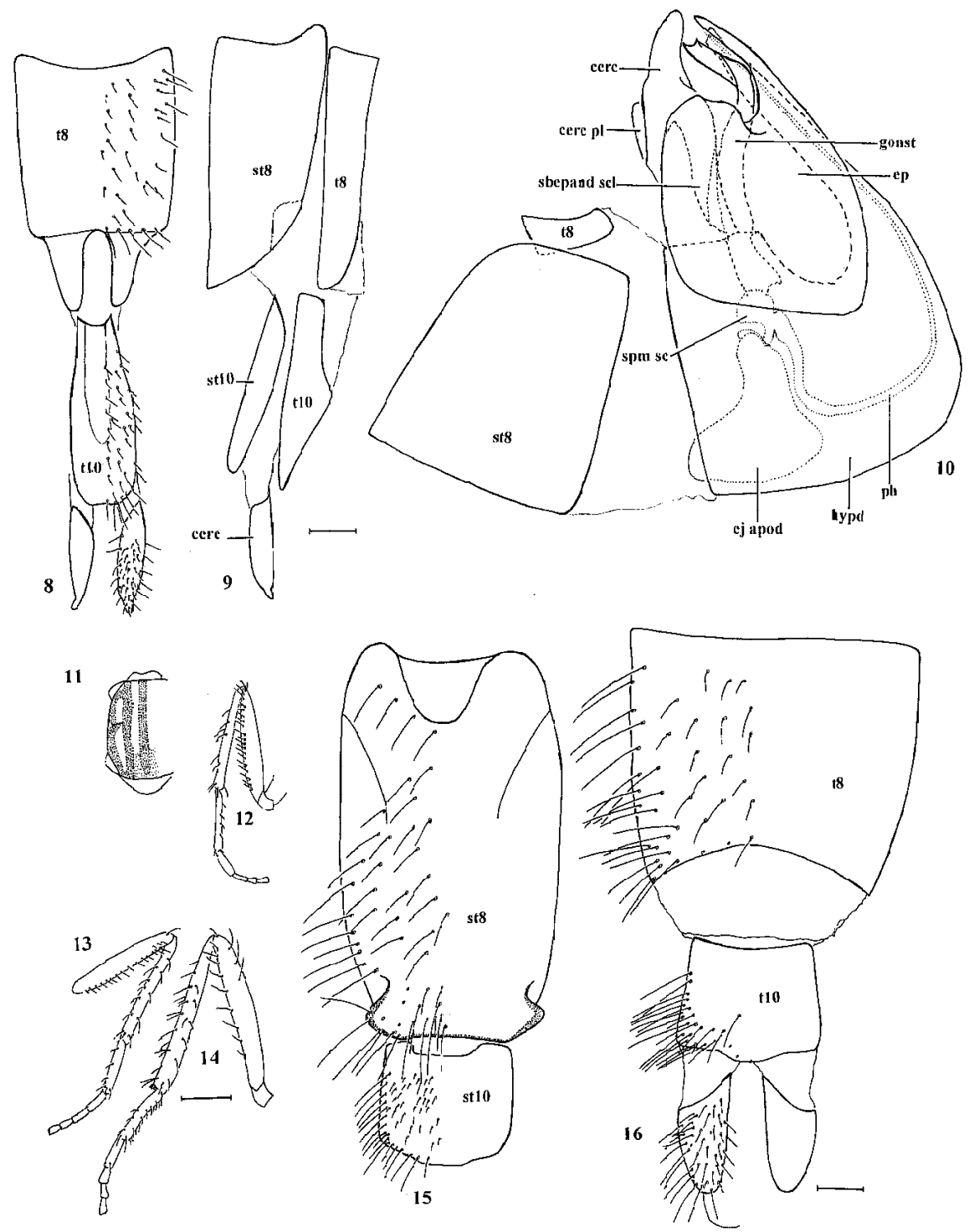

Figs. 8-16. Terminalia of Aplomera gayi: 8, female, dorsal view (holotype); 9, female, left lateral view, bristles not represented (holotype); 10, male, left lateral view, bristles not represented (holotype $\sigma^{n}$ of Aplomera nudipes). Empis polita, female lectotype: 11, thorax, dorsal view (sketch showing pruinosity pattern); 12, left fore leg, posterior view; 13, left mid leg, anterior view; 14, right hind leg, anterior view; 15, terminalia, ventral view (cerci omitted); 16, terminalia, dorsal view. Abbreviations: cerc, cercus; cerc pl, cercal plate; ej apod, ejaculatory apodeme; ep, epandrium; gonst, gonostyle; hypd, hypandrium; ph, phallus; sbepand scl, subepandrial sclerite; spm sc, sperm sac; st, sternite; t, tergite. Bars: 0,5 mm, figs. 12-14; 0,1 mm, figs. 8-10, 15,16. 


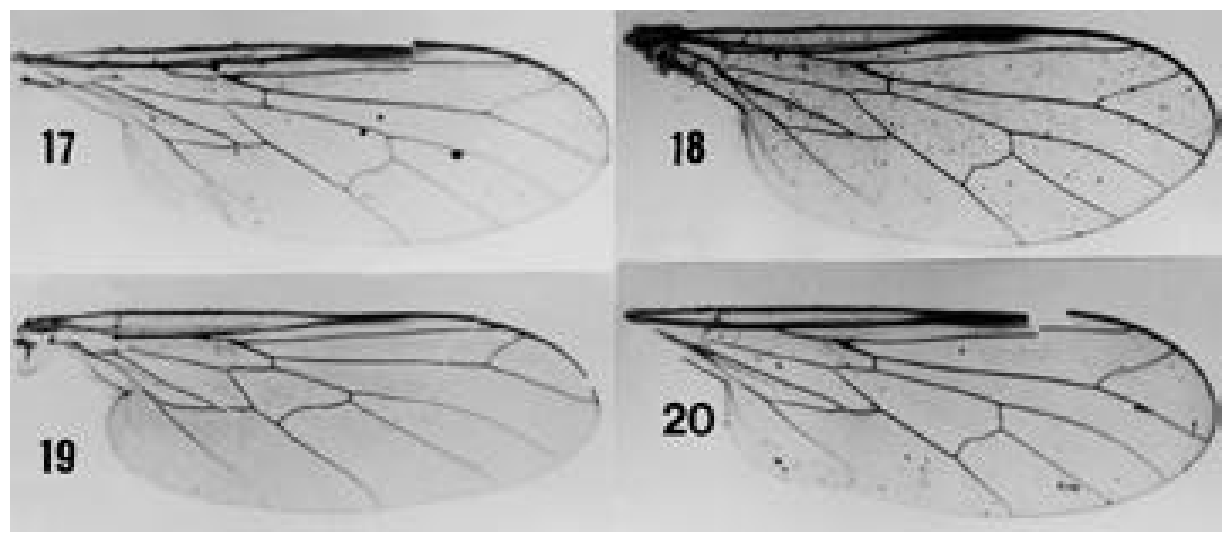

Figs. 17-20. Wings, dorsal view. 17, Aplomera pachymera (lectotype $\sigma^{-1}$ of Aplomera chilensis), 4,5 $\mathrm{mm} ; 18$, A. gayi ( holotype), 5,9 mm; 19, Empis polita (Ylectotype), 5,7 mm; 20, A. gayi (holotype of Aplomera nudipes), $5,7 \mathrm{~mm}$.

spaced anteroventral, posteroventral, anterodorsal and posterodorsal bristles, besides 1 posterior and 1 anterior bristle at apex; first tarsomere with 4 anteroventral and posteroventral bristles equally spaced, besides 1 anterior and 1 dorsal bristle at apex. Hind tibia (fig. 14) with rows of 6-8 anterodorsal, posterodorsal, anteroventral bristles equally spaced, besides 1 posterior close to the comb and 3 anterior bristles, being 1 subapical and 2 apical; first tarsomere with rows of 5-6 anteroventral and posteroventral equally spaced bristles, besides 1 anterior and 1 posterior bristle at apex (according to Collin redescription, hind trochanter with a row of 3-4 blunt black spines that was not observed). Wing (fig. 19) with brown veins; vein $\mathrm{R}_{1}$ not dilated at apex; cell dm small; $R_{5}$ vein ending near wing tip; $A_{1}$ almost reaching wing margin. Halter and calypter yellow.

Abdomen. Shinning black and according to light incidence gray pruinose at bases of tergites, broad at base, pointed towards tip, with longest black bristles at sides of tergites 1-2. Sternites and tergites concolorous. Terminalia (figs. 15, 16). Sternite 8 with lateral process on apex; cerci short.

Male. Described adequately by CoLLin (1933) in comparison with E. variabilis, together with female redescription. Terminalia as in fig. 7.

Material examined. Lectotype 9 (pres. desig.) (MNHN) [green rounded label with under face manuscript number] "670 97" / [white label with manuscript name] "Empis polita" / [white label manuscript] "no 1578, E. polita Macquart, 2 spéc." / [a blue label added by this author] "Lectotype Y, Empis polita Macq., des. J.A.Rafael"; Paralectotype 9 , idem. CHILE, Santiago, Penalolén, 10.X.1953, L.E. Pena (5 $\sigma^{\prime \prime}, 8$ CNC); Valparaiso, MargaMarga, 11-12.IX.1954, L.E. Pena ( $3 \sigma^{\circ}, 20$ ९ CNC; 20 , 3 INPA).

Lectotype condition. Body covered with dry fungi. Right wing partially damaged at level of Sc vein; left wing mounted on a microslide and terminalia placed in a microvial. Paralectotype with right wing mounted on a microslide.

Note. According to ColLiN (1933:234) this species belongs to group II of Empis. 
Acknowledgements. Dr. L. Tsacas, Laboratoire d'Entomologie (MNHN) for the loan of the Macquart's types; Dr. U. Kalweitt (SMT) for the loan of Bezzi's types and Dr. Jeffrey Cumming (CNC) for the facilities during my stay in Ottawa, Canada.

\section{REFERENCES}

Bezzi, M. 1905. Empididae neotropicae Musei Nationalis Hungarici. Annls hist.-nat. Mus. natn. hung. Budapest, 3:424-460.

. 1909. Beiträge zur Kenntniss der südamerikanischen Dipterenfauna. Fam. Empididae. Nova Acta Acad. Caesar. Leop. Carol., Halle, 91:297-406.

Collin, J.E. 1933. Empididae. In: Diptera of Patagonia and South Chile. London, British Museum of Natural History, v.4, 334 p.

Cumming, J.M.; Sinclair, B.J. \& Wood, D.M. 1995. Homology and phylogenetic implications of male genitalia in Diptera-Eremoneura. Ent. Scand., Copenhagen, 26:120-151.

ICZn (InTERnational Commission on Zoological Nomenclature). 1985. International Code of Zoological Nomenclature. 3. ed., adopted by the XX General Assembly of the International Union of Biological Sciences. London, International Trust for Zoological Nomenclature. 338 p.

Macquart, J. 1838. Diptères exotiques nouveaux ou peu connus. Mém. Soc. Sci. Agric. Lille, (Suppl.), Paris, 1838:121-323.

. 1846. Diptères exotiques nouveaux ou peu connus. Mém. Soc. Sci. Agric. Lille, (Suppl.), Paris, 1844:133364.

McAlpine, J.F. 1981. Morphology and terminology. In: McAlpine J.F. et al. eds. Manual of Nearctic Diptera. Ottawa, Res. Branch, Agriculture Canada. v. 1, p. 9-63. (Monograph n. 27).

Melander, A.L. 1928. Diptera, Fam. Empididae. In: Genera Insectorum. Bruxelles, P. Wystman. v. 185, 434 p. PHILIPPI, R.A. 1865. Aufzählung der chilenischen Dipteren. Verh. zool.-bot. Ges. Wien, Wien, 15:595-782.

SмIтH, K.G.V. 1961. On the genus Macrostomus Wiedemann (Diptera: Empididae) with notes on the included species and new synonymy. Proc. R. ent. Soc. Lond., (B), London, 30(3-4):53-56.

. 1967. Family Empididae (Empidae, Hybotidae). In: A catalogue of the Diptera of the Americas South of the United States. São Paulo, Departamento de Zoologia, Secretaria de Agricultura. v. 39, 67 p.

Recebido em 11.04.2000; aceito em 04.09.2000. 